\title{
Use of vitamin $D$ and infection in patients with chronic kidney disease
}

\author{
Uso da vitamina $D$ e infecção em pacientes com doença renal crônica \\ Uso de la vitamina $D$ e infección en pacientes con enfermedad renal crónica
}

\section{Emanuela Cardoso da Silva', Mônica Taminato', Cassiane Dezoti da Fonseca', Graciana Maria de Moraes', Maria Cristina Barbosa Longo', Cibele Esmanhoto Grothe', Angélica Gonçalves Silva Belasco', Dulce Aparecida Barbosa'}

' Universidade Federal de São Paulo, Paulista Nursing School. São Paulo, São Paulo, Brazil.

\section{How to cite this article:}

Silva EC, Taminato M, Fonseca CD, Moraes GM, Longo MCB, Grothe CE, et al. Use of vitamin D and infection in patients with chronic kidney disease. Rev Bras Enferm [Internet]. 2018;71(Suppl 6):2792-9. [Thematic Issue: Good practices in the care process as the centrality of the Nursing] DOI: http://dx.doi.org/10.1590/0034-7167-2018-0640

\section{Submission: 08-02-2018 Approval: 08-07-2018}

\section{ABSTRACT}

Objective: To evaluate the effectiveness of vitamin D supplementation as protection factor against infection of patients with chronic kidney disease on conservative treatment. Method: Retrospective cohort study carried out between 2013 and 2016 in the Conservative Treatment Outpatient Clinics (Ambulatório de Tratamento Conservador) of the Hypertension and Kidney Hospital (Hospital do Rim e Hipertensão) of the Universidade Federal de São Paulo. Data on sociodemographic factors, comorbidity, infection episodes and use or nonuse of vitamin D supplementation for at least 6 months were collected from medical records. The primary outcomes considered in both groups were: presence or absence of infection anywhere on the body (bloodstream, urinary, respiratory and surgical sites). Results: A total of 263 patients were included and those who received $(n=43)$ vitamin D had $59 \%$ less chance of developing infections (OR $=0.41 ; 95 \% \mathrm{Cl} ; 0.15-0.99)$, when compared to those who did not receive. Conclusion: Vitamin D supplementation was a protective factor against infections of all causes.

Descriptors: Renal Insufficiency; Conservative Treatment; Vitamin D; Infection; Nephrology.

\section{RESUMO}

Objetivo: avaliar a efetividade da suplementação de vitamina $\mathrm{D}$ em pacientes com doença renal crônica em tratamento conservador como fator de proteção contra infecções. Método: Estudo de Coorte retrospectiva realizado entre 2013 e 2016 no Ambulatório de Tratamento Conservador do Hospital do Rim e Hipertensão da Universidade Federal de São Paulo. Foram coletados dos prontuários os dados sociodemográficos, de comorbidade, episódios de infecção, em uso ou não de suplementação de vitamina $D$ por no mínimo 6 meses. Os desfechos primários considerados nos dois grupos foram: a presença ou não de infecção em qualquer sítio: urinário, respiratório, corrente sanguínea e sítio cirúrgico. Resultados: Foram incluídos 263 pacientes e os que receberam $(n=43)$ vitamina $D$ tiveram $59 \%$ menos chance de desenvolver infecção (OR $=0,41 ;$ IC95\% 0,15-0,99), quando comparados aos que não receberam. Conclusão: A suplementação de vitamina $D$ foi fator de proteção contra infecções de todas as causas.

Descritores: Insuficiência Renal; Tratamento Conservador; Vitamina D; Infecção; Nefrologia.

\section{RESUMEN}

Objetivo: evaluar la efectividad de la suplementación de vitamina D en pacientes con enfermedad renal crónica en tratamiento conservador como factor de protección contra infecciones. Método: Estudio de Cohorte retrospectiva realizado entre 2013 y 2016 en el Ambulatorio de Tratamiento Conservador del Hospital do Rim e Hipertensão da Universidade Federal São Paulo. Se recogieron de los prontuarios los datos sociodemográficos, de comorbilidad, episodios de infección, en uso o no de suplementación de vitamina D por lo menos 6 meses. Los resultados primarios considerados en los dos grupos fueron: la presencia o no de infección en cualquier sitio: urinario, respiratorio, corriente sanguínea y sitio quirúrgico. Resultados: Se incluyeron 263 pacientes y los que recibieron $(n=$ 43) vitamina $D$ tenían un 59\% menos de posibilidades de desarrollar infección (OR = 0,41, IC95\% 0,15-0,99), en comparación con los que no recibieron. Conclusión: La suplementación de vitamina $D$ fue factor de protección contra infecciones de todas las causas. Descriptores: Insuficiencia Renal; Tratamiento Conservador; Vitamina D; Infección; Nefrología. 


\section{INTRODUCTION}

Kidney disease has become a global public health problem in recent decades. Researchers estimate that prevalence of kidney disease in world population ranges from 8 to $16^{(1-2)}$. Among several metabolic implications, the kidney disease is a risk factor for the decrease in levels of vitamin D, which means there is a significant number of people with potential risk of presenting complications resulting from vitamin D deficit/insufficiency ${ }^{(3-5)}$.

Such complications involve the development of metabolic bone, cardiovascular, infectious and autoimmune diseases, neoplasms, hyperparathyroidism, type 2 diabetes mellitus, and increase in albuminuria (essential marker for predicting decrease in renal function and, consequently, renal insufficiency) ${ }^{(3,5-7)}$.

The determination of vitamin $\mathrm{D}$ levels in the organism must be carried out through serum dosage of 25-hydroxyvitamin $\mathrm{D}(25(\mathrm{OH})$ D), given that 1,25 -dihydroxyvitamin $\mathrm{D}\left(1,25 \mathrm{OH}_{2} \mathrm{D}_{3}\right)$ is in lesser quantity in the bloodstream and has half-life less than the one of $25(\mathrm{OH}) \mathrm{D}$. We highlight that the vitamin D deficit increases the secretion of parathyroid hormone (PTH), which consequently causes the kidney to produce more $1,25 \mathrm{OH}_{2} \mathrm{D}_{3}$. In other words, serum levels of $1,25 \mathrm{OH}_{2} \mathrm{D}_{3}$ will remain unchanged or, in some cases, increased ${ }^{(8-9)}$.

From the discovery that several other tissues and cells feature vitamin D receptors, being able to convert $(25(\mathrm{OH}) \mathrm{D})$ into $\left(1,25(\mathrm{OH})_{2} \mathrm{D}_{3}\right)$, active form of vitamin $\mathrm{D}$, it became imperative to study its various functions and the mechanism of action of these receptors ${ }^{(4,7-8)}$.

The immune system has an important role in the mechanisms of action of vitamin $\mathrm{D}$. It regulates the inhibition and/or activation of several defense cells (monocytes, lymphocytes, among others) through differentiation and activation of CD4; expands the action of regulatory $\mathrm{T}$ cells; and inhibits the differentiation of monocytes in dendritic cells, thus decreasing the production of interferon- $\gamma$, IL-2 and TNF- $\alpha$, which stimulates Th2 helper cells, inhibiting the generation of IL-17 originating from Th1720 and promotes the increase of natural killer T cells $s^{(6,8,10)}$.

Thus, vitamin $\mathrm{D}$ deficiency has been associated with the increase in prevalence of autoimmune diseases as: rheumatoid arthritis, systemic lupus erythematosus, undifferentiated connective tissue disease, inflammatory bowel disease, multiple sclerosis and type 1 diabetes ${ }^{(6,8)}$. Additionally, one can relate the function of $1,25(\mathrm{OH})_{2} \mathrm{D}_{3}-\mathrm{VDR}$ (innate and adaptive) immunity to infections through the immunoregulatory action of vitamin $\mathrm{D}$ in the parathyroid. Therefore, a vitamin D deficit can result in hyperparathyroidism and increase the risk of infection ${ }^{(7-8)}$.

The Healthcare-Associated Infections (HAI) are related to high mortality and morbidity rates ${ }^{(11)}$. The chronic kidney disease (CKD) is an important risk factor for the development of HAl. Urinary tract infection and pneumonia were reported with higher incidence in patients with chronic kidney diseases ${ }^{(11-12)}$. The unfavorable clinical picture of vitamin D deficit in kidney disease favors and potentiates the occurrence of HAI. Vitamin D deficiency has been related to the increase in morbidity by cardiovascular and infectious diseases in patients diagnosed with kidney disease ${ }^{(5)}$. Evidence show that there are functional deficit and hyperstimulation of the immune system. This fact is related to the increase in the risk of people with chronic kidney disease developing local and generalized infections, as well as to the interference in the expected immune response after immunization ${ }^{(6)}$.

There is no consensus about vitamin $\mathrm{D}$ supplementation being associated with decrease in infection rates of all causes. Studies conducted in 2013 and 2015 on patients with chronic kidney disease undergoing hemodialysis ${ }^{(13-14)}$ found no association between use of oral vitamin D and reduction of infection. On the other hand, studies conducted in the United States of America (USA) in 2003 and $2005^{(15-16)}$ considered the replacement of vitamin D a valid strategy to reduce morbidity and mortality of people with kidney diseases, especially the ones of cardiovascular and infectious causes $^{(5)}$.

Recently, in vivo studies have shown that $1,25(\mathrm{OH})_{2} \mathrm{D}_{3}$ assists the stimulation of monocytes and macrophages, potentializing their antibacterial effect and acts as immunosuppressant in lymphocytes. A preclinical study showed that $1,25(\mathrm{OH})_{2} \mathrm{D}_{3}$ helped to inhibit transplant rejection, being more effective than cyclosporine A (heart transplantation), and to reduce the risk of infection. For kidney transplantation, the vitamin D prolonged the function of the transplanted organ ${ }^{(9-10)}$.

Given this panorama, the therapeutic use of vitamin D has been considered not only for treatment of hyperparathyroidism, but also as strategy to reduce morbidity and mortality associated with cardiovascular and infectious diseases, considering its role as important immune modulator ${ }^{(6)}$. In addition, the use of calcitriol as an adjuvant of influenza vaccine was effective to enhance the immune respons $\mathrm{e}^{(5,10)}$.

Considering the magnitude of kidney disease and its association with vitamin D deficit/insufficiency, our study proposes to answer the following question: is there an association between vitamin D supplementation in patients under conservative treatment with decrease in the occurrence of infections? The choice of this subject can be explained by the non-standardization of vitamin $\mathrm{D}$ utilization as prophylaxis of infections in patients with kidney disease and by the need of seeking evidence that could corroborate this practice.

\section{OBJECTIVE}

To evaluate the effectiveness of vitamin D supplementation as protection factor against infections of patients with chronic kidney disease on conservative treatment.

\section{METHOD}

\section{Ethical Aspects}

This project was approved by the Research Ethics Committee of the Universidade Federal de São Paulo, in compliance with the standards ${ }^{(17)}$ of the Brazilian National Health Council.

\section{Study design and location}

Retrospective cohort study ${ }^{(18)}$ carried out in the Conservative Treatment Outpatient Clinics (Ambulatório de Tratamento Conservador) of the Hypertension and Kidney Hospital (HRim - Hospital do Rim e Hipertensão) of the Universidade Federal de São Paulo. This outpatient clinics is part of the HRim infrastructure, which consists of clinical analysis laboratories, services of pathologic anatomy, imaging and hemodynamic diagnostic unit and surgical center, where transplantations 
and videolaparoscopies of urinary and digestive apparatus are performed, in addition to cardiac and vascular surgeries.

The several outpatient clinics that are part of the HRim treat approximately 500 people/day, providing healthcare in pre- and posttransplantations, dialysis, conservative treatment and appointments conducted by a multidisciplinary team. It is an institution of national and international reference in teaching, research and healthcare.

\section{Population}

A convenience sample was used. The initial sample of the study consisted of medical records of patients treated in the outpatient clinics for at least one year and who attended at least one medical appointment between January 01, 2013 and December 31, 2016. Subsequently, patients were subjected to the inclusion criteria listed below:

1. Patient's medical record available at the time of data collection;

2. Patients on conservative treatment older than 18 and of both sexes;

3. Patients with or without previous infection episode reported in the medical record;

4. Patients on use or nonuse of vitamin D supplementation for at least 6 months;

Patients whose medical records were not located during data collection or whose treatment was other than the conservative one were excluded from the sample.

\section{Study protocol}

The instrument used for data collection consisted of sociodemographic variables (age, sex, race, profession); comorbidities (high blood pressure, diabetes mellitus, cardiovascular diseases, others); infection episodes; and vitamin D supplementation.

Infection was considered as dependent variable, and use or nonuse of vitamin D, sociodemographic data age, sex, race, profession), and comorbidity (high blood pressure, diabetes mellitus, cardiovascular diseases, others) were considered as independent variables. Two groups were considered:

Group A - patients on use of vitamin D supplementation for at least 6 months;

Group B - patients on nonuse of vitamin D supplementation.

The primary outcome considered in both groups was the presence or absence of infection. Infection is a medical condition caused by pathological microorganisms that, due to the pathophysiology of chronic kidney disease, may cause negative impact on the health status of this population, contributing to increase morbidity and mortality ${ }^{(19-20)}$.

Thus, this study considered as infection episode the occurrence of any infectious process anywhere on the body. The option in using the delimitation of the Brazilian Health Regulatory Agency (Anvisa) regarding the classification of Healthcare-Associated Infections (HAI) is justified by the shortage of literature that could support the methodological approach adopted and because it was impossible to determine, in all cases, whether the source of the infection was the community or associated with the healthcare service ${ }^{(11)}$.
Thus, the infection episodes identified were grouped into four large groups, considering the current recommendations regarding the $\mathrm{HAl}$ used in Brazil. They are: urinary tract infection (UTI), respiratory tract infection (RTI), bloodstream infection (BSI) and surgical site infection (SSI). The infection episode was validated through confirmation of registration in the medical record of the doctor's evaluation and clinical diagnosis and/or result of one or more positive cultures of any micro-organism through blood culture, urine culture, bronchoalveolar lavage or surgical wound secretion ${ }^{(11)}$.

\section{Analysis of results and statistics}

Initially, the descriptive analysis of quantitative and categorical variables were conducted and results were presented in absolute and relative frequencies. In the bivariate exploratory analysis (Table 2), the association between infection (outcome variable) and other variables (exposure variables) was tested, being the use of Vitamin D the main variable. The chi-square test considered significant the results with $p<0.05$. Odds Ratio (OR) was the measure of association used in the bivariate analysis and its confidence interval was set at $95 \%$.

\section{RESULTS}

A total of 263 medical records were analyzed, of which $52.85 \%$ were male patients, $60.46 \%$ were white and $56.65 \%$ were 66 or older. Regarding the associated comorbidities, most patients of both sexes had systemic high blood pressure $(88.21 \%)$. Of the total, $45.25 \%$ of patients had diabetes mellitus and $69.58 \%$ had other diseases (Table 1).

Table 1 - Sociodemographic data of patients with chronic kidney disease on conservative treatment, São Paulo, Brazil, 2018

\begin{tabular}{|c|c|c|}
\hline Variables & $\mathbf{n}$ & $\%$ \\
\hline \multicolumn{3}{|l|}{ Sex } \\
\hline Male & 139 & 52.85 \\
\hline Female & 124 & 47.14 \\
\hline \multicolumn{3}{|l|}{ Age group } \\
\hline $18-33$ & 13 & 4.94 \\
\hline $34-49$ & 21 & 7.98 \\
\hline $50-65$ & 77 & 29.28 \\
\hline 66 or older & 149 & 56.65 \\
\hline Without information & 3 & 1.14 \\
\hline \multicolumn{3}{|l|}{ Race } \\
\hline White & 159 & 60.46 \\
\hline Black & 84 & 31.94 \\
\hline Without information & 20 & 7.60 \\
\hline \multicolumn{3}{|l|}{ Occupation } \\
\hline Retired patients/pensioners & 55 & 20.21 \\
\hline Other & 116 & 44.11 \\
\hline Without information & 92 & 34.99 \\
\hline \multicolumn{3}{|l|}{ Comorbidities } \\
\hline Diabetes mellitus & 119 & 45.25 \\
\hline High blood pressure & 232 & 88.21 \\
\hline Cardiovascular diseases & 57 & 21.67 \\
\hline Other & 183 & 69.58 \\
\hline
\end{tabular}

Source: Database of patients on conservative treatment. 
Table 2 - Bivariate analysis of the relationship between main exposure variable (vitamin D) and outcome (infection), São Paulo, Brazil, 2018

\begin{tabular}{lccccc}
\hline \multicolumn{1}{c}{ Variables } & $\begin{array}{c}\text { Use of } \\
\text { Vitamin D }\end{array}$ & $\begin{array}{c}\text { Nonuse of } \\
\text { Vitamin D }\end{array}$ & $\begin{array}{c}\text { Total } \\
(\mathbf{n})\end{array}$ & \% & $\begin{array}{c}\text { Proportion } \\
\text { Exposure }\end{array}$ \\
\hline With infection & 7 & 71 & 78 & 29.65 & 0.1628 \\
Without infection & 36 & 149 & 185 & 70.34 & 0.3237 \\
Total & 43 & 220 & 263 & 100 & 0.2966 \\
\hline
\end{tabular}

Source: Database of patients on conservative treatment.

Table 3 - Distribution of infection cases among people with chronic kidney disease on conservative treatment by site, São Paulo, Brasil, 2018

\begin{tabular}{lcccc}
\hline \multicolumn{1}{c}{ Site } & $\begin{array}{c}\text { Use of } \\
\text { Vitamin D }\end{array}$ & $\begin{array}{c}\text { Nonuse of } \\
\text { Vitamin D }\end{array}$ & \multicolumn{2}{c}{ Total } \\
$\mathbf{n}$ & $\mathbf{\%}$ \\
\hline Bloodstream infection & 2 & 5 & 7 & 8.97 \\
Urinary tract infection & 3 & 65 & 68 & 87.18 \\
Respiratory tract infection & 2 & 1 & 3 & 3.85 \\
Total & 07 & 71 & 78 & 100 \\
\hline
\end{tabular}

Source: Database of patients on conservative treatment.
Table 4 - Microorganisms identified in cultures performed in patients with chronic kidney disease on conservative treatment who presented site infection, São Paulo, Brazil, 2018

\begin{tabular}{lcccc}
\hline \multicolumn{1}{c}{ Microorganisms } & $\begin{array}{c}\text { Urinary } \\
\text { tract } \\
\text { infection }\end{array}$ & $\begin{array}{c}\text { Respiratory } \\
\text { tract } \\
\text { infection }\end{array}$ & Total & n \\
\hline Gram-positive bacteria & 1 & & & \\
$\quad$ Staphylococcus aureus & 1 & 1 & 1.41 \\
Coagulase-negative staphylococcus & 1 & & 1 & 1.41 \\
$\quad$ Enterococcus spp. & 4 & & 4 & 5.63 \\
Gram-negative bacteria & 35 & 1 & 36 & 50.70 \\
$\quad$ Escherichia coli & 12 & & 12 & 16.90 \\
Klebsiella pneumoniae & 1 & & 1 & 1.41 \\
$\quad$ Klebsiella oxytoca & 1 & & 1 & 1.41 \\
Morganella morganii & 3 & & 3 & 4.23 \\
Proteus mirabilis & 1 & & 1 & 1.41 \\
$\quad$ Pseudomonas aeruginosa & 3 & & 3 & 4.23 \\
Enterobacter spp. & 6 & 2 & 8 & 11.26 \\
Culture not available & 68 & 3 & 71 & 100 \\
Total & & & & \\
\hline
\end{tabular}

Source: Database of patients on conservative treatment.
Approximately $29.66 \%$ of patients had hypovitaminosis $\mathrm{D}$, to whom a vitamin replacement therapy was established. Table 2 shows that among the 43 patients who used vitamin D supplementation, only 7 (16.27\%) had infection. Among the 185 who used no vitamin D supplementation, 71 (32.27\%) had infection somewhere on the body.

Table 3 shows the distribution of infection cases by type. The UTI was the most common among patients, regardless of use or nonuse of vitamin D supplementation, corresponding to $87.18 \%$ of the total.

Table 4 demonstrates which microorganisms were isolated in the cultures performed in patients with respiratory and urinary tract infection. Most of them, $91.55 \%$, consisted of gram-negative microorganisms. The most frequent bacteria was the Escherichia coli (50.70\%), followed by the Klebsiella pneumoniae which appeared in $16.90 \%$ of cases.

Table 5 shows the results for bivariate analysis and the relationship between main exposure variable (vitamin D) and outcome (infection). The relationship between main exposure variable (vitamin D) and outcome (infection) had a $95 \% \mathrm{Cl}$ less than 1, with statistical significance.
Table 5 - Occurrence of infection according to sociodemographic and clinical variables of cases, São Paulo, Brazil, 2018

\begin{tabular}{|c|c|c|c|c|c|c|}
\hline & \multicolumn{2}{|c|}{ Infection } & \multirow{2}{*}{$\begin{array}{c}\text { OR } \\
(95 \% \mathrm{Cl})\end{array}$} & \multirow{2}{*}{$p$ value } & \multirow{2}{*}{$\begin{array}{c}\text { OR } \\
(95 \% \mathrm{Cl})\end{array}$} & \multirow{2}{*}{$p$ value } \\
\hline & Yes & No & & & & \\
\hline \multicolumn{7}{|l|}{ Sex } \\
\hline Female & 43 & 86 & 1 & & & \\
\hline Male & 35 & 99 & $0.71(0.40-1.24)$ & 0.20 & $0.64(0.37-1.11)$ & 0.11 \\
\hline \multicolumn{7}{|l|}{ Age group } \\
\hline $18-33$ & 1 & 12 & 1 & & & \\
\hline $34-49$ & 8 & 13 & $7.38(0.75-354.38)$ & 0.05 & $8.97(0.92-87.41)$ & 0.06 \\
\hline $50-65$ & 19 & 58 & $3.93(0.51-176.72)$ & 0.17 & $4.12(0.48-35.55)$ & 0.20 \\
\hline 66 or older & 50 & 99 & $6.06(0.85-264.12)$ & 0.05 & $6.04(0.73-50.15)$ & 0.10 \\
\hline \multicolumn{7}{|l|}{ Race } \\
\hline White & 44 & 115 & 1 & & & \\
\hline Black & 23 & 61 & $0.99(0.52-1.85)$ & 0.96 & $1.00(0.54-1.83)$ & 0.99 \\
\hline Ignored & 11 & 9 & $3.19(1.11-9.31)$ & 0.01 & 3.07 (1.15-8.18) & 0.03 \\
\hline \multicolumn{7}{|c|}{ Diabetes mellitus } \\
\hline No & 42 & 102 & 1 & & & \\
\hline Yes & 36 & 83 & $1.05(0.60-1.85)$ & 0.85 & & \\
\hline \multicolumn{7}{|c|}{ High blood pressure } \\
\hline No & 9 & 21 & 1 & & & \\
\hline Yes & 69 & 164 & $0.98(0.41-2.56)$ & 0.97 & & \\
\hline \multicolumn{7}{|c|}{ Cardiovascular disease } \\
\hline No & 57 & 148 & 1 & & & \\
\hline Yes & 21 & 37 & $1.47(0.75-2.84)$ & 0.22 & & \\
\hline \multicolumn{7}{|c|}{ Use of vitamin D } \\
\hline No & 71 & 149 & 1 & & & \\
\hline Yes & 7 & 36 & $0.41(0.15-0.99)$ & 0.03 & $0.48(0.20-1.15)$ & 0.10 \\
\hline
\end{tabular}

Source: Database of patients on conservative treatment. 
Thus, we can consider that the use of vitamin D is a "protection factor" for infection. The use of vitamin D is a protector factor against infection, without being adjusted by the presence of other variables (e.g., age, sex, etc). That is, cases that received vitamin $\mathrm{D}$ had $59 \%$ less chance of developing infection $(\mathrm{OR}=0.41 ; 95 \% \mathrm{Cl} ; 0.15-0.99)$ when compared to those who did not receive.

To the multivariate analysis were included the covariates sex, race, age group, in addition to the main variable, use of vitamin D. In this case, the statistical significance did not remain, probably because some of the covariates modified the effect. The main risk factors found were age in the age group $34-49$ years $(\mathrm{OR}=8.97 ; 95 \% \mathrm{Cl} ; 0.92-87.41)$ and older than $66(\mathrm{OR}=6.04 ; 95 \% \mathrm{Cl} ; 0.73-50.15)$.

\section{DISCUSSION}

Vitamin D supplementation has been a practice in patients with chronic kidney disease (CKD), because their renal tubular cells are unable to produce 1,25-dihydroxyvitamin D, precursor substance of the 25-hydroxyvitamin D, which is the active form of vitamin D. This study noticed the additional action of vitamin $\mathrm{D}$ as a protective agent against healthcare-associated infections. This investigation was a pioneer among patients with chronic kidney disease on conservative treatment of a national reference institution for kidney dysfunction.

Therefore, this study had as main objective to assess whether vitamin D supplementation in patients with chronic kidney disease on conservative treatment acts as a protective factor against infections and as secondary objectives to identify the association between the occurrence of infection with use of vitamin D and to identify the microorganisms isolated in the cultures of these patients. We opted for the retrospective cohort design following the recommendations proposed by the Strengthening the Reporting of Observational Studies in Epidemiology (STROBE) (18) to answer the question of the study.

With the increase in Brazilians' life expectancy over the past decades, one can note the growth in incidence and prevalence of chronic diseases such as high blood pressure and diabetes mellitus, which are the main causes of chronic kidney disease, especially in older persons ${ }^{(20)}$.

Brazilian and world prospects have similar increasing rates. However, in developed countries, the prevalence maintains a constant growth and the incidence remains stable or presents a discrete elevation ${ }^{(21-22)}$. In 2015, 124,114 new cases of chronic kidney disease occurred in the USA. Individuals affected the most were female (15.1\%), older than 60 (33.2\%), and white $(13.9 \%)$. The associated comorbidities were diabetes mellitus $(39.2 \%)$ and high blood pressure $(31 \%)^{(21)}$.

In 2016, according to data from the Brazilian Society of Nephrology (SBN - Sociedade Brasileira de Nefrologia), 122,825 patients with end stage renal disease (ESRD) were on hemodialysis. Prevalence and incidence rates were, respectively, 596 and 193 patients per million population (pmp). Most of these individuals (57\%) were male, older than 65 (33\%), whose diagnosis of primary kidney disease were, respectively, high blood pressure (34\%) and diabetes mellitus $(30 \%)^{(23)}$.
A retrospective study with data on 1,120,295 people in Northern California showed that $54.6 \%$ were female and $50.9 \%$ were white. This investigation demonstrated association between lower levels of glomerular filtration rate (GFR) with mortality, cardiovascular diseases and hospitalization. In this context, $33.7 \%$ of patients with high blood pressure and $12.3 \%$ with diabetes mellitus were detected in stage 3 (GFR between 45-59 $\mathrm{mL} / \mathrm{min} / 1.73 \mathrm{~m}^{2}$ ) in DRC, with considerable elevation to $50.3 \%$ with high blood pressure and $31.1 \%$ with diabetes mellitus in stage $5\left(\text { GFR }<15 \mathrm{~mL} / \mathrm{min} / 1.73 \mathrm{~m}^{2}\right)^{(24)}$.

In our study, we observed a higher percentage of occurrences in male patients, corresponding to $52.85 \%$ of the studied population, with $60.46 \%$ being white and having high blood pressure as the main cause of primary kidney disease, as well as $88.21 \%$ of patients in our study.

Considering the data from developed countries, we noted a small discrepancy regarding the sex and the primary cause of chronic kidney disease, which can suggest specificities of the population studied. Such hypothesis can be supported by a study carried out in 2009 in Recife (PE), which showed that most individuals analyzed were female $(56 \%)^{(25)}$.

In this study, $29.66 \%$ of the sample had vitamin D deficiency. The supplementation of these patients was performed through the protocol used in the institution, which considered the serum rates of each patient: $<20 \mathrm{ng} / \mathrm{mL}$ loading dose for 3 months; 20-19 ng/mL loading dose for 3 months; > $30 \mathrm{ng} / \mathrm{mL}$ maintenance dose. Vitamin D deficiency is associated with risk factors such as black race, obesity, diabetes mellitus, among others ${ }^{(26)}$.

In this context, low levels of 25-hydroxyvitamin D $(25(\mathrm{OH})$ D) are common in patients with chronic kidney disease. The prevalence of this condition increases as the kidney function decreases. Factors as age and comorbidities (diabetes mellitus and high blood pressure) have been associated with low levels of $25(\mathrm{OH}) \mathrm{D}$ in patients with CKD (on dialysis or conservative treatment) ${ }^{(27)}$.

A preclinical study investigated the relationship of vitamin $\mathrm{D}$ deficiency with progression of chronic kidney disease. The authors found an increase in gene expression of compounds of the renin-angiotensin system, in levels of aldosterone in plasma and in presence of tubulointerstitial injury with formation of interstitial fibrosis in experimental groups submitted to Vitamin $\mathrm{D}$ deficiency ${ }^{(28)}$.

Additionally, a cross-sectional research performed in 2,895 patients with CKD assessed the relationship of vitamin $\mathrm{D}$ values with CKD stage. Rates of $\leq 30 \mathrm{ng} / \mathrm{mL}$ and $<10 \mathrm{ng} / \mathrm{mL}$ were set in $84.7 \%$ and $11.3 \%$ of patients classified with stage 5 of CKD. On the other hand, for the respective rates, $66.6 \%$ and $1.9 \%$ of patients were classified with stage 3 . These findings demonstrate the significant association of progression of chronic kidney disease with hypovitaminosis $\mathrm{D}^{(29)}$.

In Bulgaria, a comparative study conducted with patients on conservative treatment or renal replacement therapy showed that $80 \%$ of subjects had vitamin D deficiency/insufficiency ${ }^{(30)}$. Similarly, in the sample of CKD patients on conservative treatment, $73.6 \%$ of them had hypovitaminosis D, considered of high frequency ${ }^{(3)}$. In addition, another research showed that, although there is no clarity on risk factors associated with vitamin 
$D$ deficiency/insufficiency in CKD patients, its prevalence is high $^{(27)}$. Such findings corroborate other studies, which showed the high prevalence of vitamin D deficiency/insufficiency in CKD patients and its association with cardiovascular diseases, hyperparathyroidism, neoplasms, type 2 diabetes mellitus, bone, immune and infectious diseases, which are the main causes of morbidity and mortality in patients with chronic kidney disease (28-31) $^{\text {. }}$

This investigation showed that $29.65 \%$ of patients had infection episode, regardless of the use or nonuse of vitamin D. From these infections, $87.18 \%$ affected the urinary tract, caused in their most by E. Coli (50.7\%).

Infection is the leading cause of morbidity and the second cause of mortality among patients on hemodialysis ${ }^{(32)}$. A retrospective cohort study associated the increase in urinary tract infections with stages 4 and 5 of chronic kidney disease ${ }^{(12)}$. Grothe $\mathrm{C}$ et al. demonstrated a $61 \%$ incidence of bloodstream infection, with major occurrence of gram-positive bacteria, being the most prevalent the $S$. aureus $(56.6 \%)^{(33)}$. Another study, a case-control study held in São Paulo between 2010 and 2013, showed that, among patients undergoing hemodialysis, the use of central venous catheter was a risk factor for bloodstream infection and that the most prevalent microorganisms were gram-positive bacteria ${ }^{(32)}$.

The recent acknowledgment that $1,25(\mathrm{OH})_{2} \mathrm{D}$ performs several functions as immunomodulator, brought to light the associations between alterations in vitamin D and occurrence of infections, which were previously inexplicable ${ }^{(34-35)}$. Low levels of $25(\mathrm{OH}) \mathrm{D}$ were associated with greater susceptibility to mycobacterial infections $(67.68 \%)$ and with recurrence of infection in patients with rickets (16-18\%). This fact reinforces the importance of studying the effects of low concentration of vitamin $\mathrm{D}$ in patients with chronic kidney disease and the likely increase of predisposition to the development of infections ${ }^{(36)}$.

In our study, the relationship between main exposure variable (vitamin D) and outcome (infection) proved the vitamin D supplementation as a protection factor against infections. Patients on vitamin D supplementation had 59\% less chance to develop an infection, when compared to those who did not receive vitamin $\mathrm{D}$. This data strengthens our hypothesis by confirming that the use of vitamin D in patients with chronic kidney disease elucidates the protective action of this substance and that it can act on preventing healthcare-associated infections.

Vitamin D disability/insufficiency can negatively influence cells of the immune system, predisposing the occurrence of infections; however, there is no consensus on the relationship infections $\times$ vitamin D. In fact, among studies that analyzed the association between vitamin D deficiency/insufficiency in patients with kidney disease and morbidity, few of them focus on infectious diseases ${ }^{(8,37-38)}$.

A multicenter study showed that vitamin D supplementation was a protection factor against infection and risk of mortality among patients on peritoneal dialysis ${ }^{(38)}$. Additionally, a cohort study performed in Japan with 508 patients on hemodialysis showed that vitamin D supplementation prevented respiratory infection, impacting the hospitalization rate of this population ${ }^{(37)}$. Another research showed that vitamin D supplementation resulted in prevention of infection and graft loss in patients with kidney transplantations ${ }^{(36)}$.

On the other hand, a case-control study held in Canada showed no positive association of vitamin D supplementation with the risk of hospitalizations by infection among patients on hemodialysis ${ }^{(13)}$. Additionally, Phyo et al. had similar results that did not relate the reduction of infection rates of all kinds with vitamin D supplementation in US patients on dialysis treatment ${ }^{(14)}$.

Summarily, despite controversial data on scientific evidence about the protective action of vitamin $\mathrm{D}$ against infections, our study highlighted that vitamin D supplementation in patients with chronic kidney disease on conservative treatment prevented healthcare-associated infections.

\section{Study limitations}

Given the retrospective design and data collected from medical records, even though the research was carried out in an international reference service on research, we could not collect the results for bloodstream infections (BSI) cultures because they were available only for medical records in the hospital, which we could not access. We can emphasize that the non-integration of information (sole electronic health record) or access to the report of patient discharge (counter-reference) are obstacles that cause a negative impact on the quality of data collected.

Contributions to the field of nursing, health or public policy

Considering the advances for the healthcare area, our study brings to light the need for prospective studies, randomized clinical trials and multicenter studies on populations with chronic kidney disease, regardless of the type of treatment (conservative or substitute) that corroborate these findings that, for now, are opposed to studies conducted, aiming at better understanding the action of vitamin D in the organism, as well as searching clinical evidence that can subsidize protocols that ensure quality in the diagnosis, proper supplementation and preventive measures aimed at reducing morbidity and mortality.

\section{CONCLUSION}

Vitamin D deficiency/insufficiency affects several patients with chronic kidney disease. Evidence on the role of vitamin $\mathrm{D}$, beyond calcium homeostasis, have been demonstrated; in particular its possible retardant action of progression of kidney damage and it function as protection factor for several pathologies, including infectious diseases.

This study demonstrated that our epidemiological data are similar to the findings of other studies, even though there are differences possibly related to the peculiarities of the sampled population. Among the infection cases, most of them affected the urinary tract and the microorganism isolated was the $E$. coli.

This study demonstrated that vitamin D supplementation in patients with chronic kidney disease on conservative treatment was a protection factor against infections of all causes. 


\section{REFERENCES}

1. Vivekanand J, Garcia-Garcia G, Iseki K, Li Z, Naicker S, Plattner B, et al. Chronic kidney disease: global dimension and perspectives. Lancet[Internet]. 2013[cited 2018 May 02];382(9888):260-72. Available from: http://www.thelancet.com/pdfs/journals/lancet/ PIIS0140-6736(13)60687-X.pdf

2. National Kidney Foundation. KDIGO 2012: Clinical Practice Guideline for the Evaluation and Management of Chronic Kidney Disease. Kidney Int Suppl[Internet]. 2013[cited 2018 Jun 09];3(1):1-163. Available from: http://www.kdigo.org/clinical practice guidelines/ pdf/CKD/KDIGO_2012_CKD_GL.pdf

3. Diniz HF, Romão MF, Elias RM, Romão JE. Vitamin D deficiency and insufficiency in patients with chronic kidney disease. J Bras Nefrol[Internet]. 2012[cited 2018 Jun 04];34(1):58-63. Available from: http://www.scielo.br/pdf/jbn/v34n1/en_a09v34n1.pdf

4. Inda Filho AJ, Melamed ML. Vitamin D and Kidney Disease: what we know and what we do not know. J Bras Nefrol[Internet]. 2013[cited 2018 Jun 04];35(4):323-31. Available from: http://www.scielo.br/pdf/jbn/v35n4/pt_v35n4a12.pdf

5. Loh ZY, Yap CW, Vathsala A, How P. Clinical and demographic predictors for vitamin D deficiency in multiethnic patients with chronic kidney disease. Clin Kidney J[Internet]. 2012[cited 2018 Jun 15];5:303-8. Available from: https://www.ncbi.nlm.nih.gov/ pmc/articles/PMC4393479/

6. Bucharles SGE. Vitamina D e o sistema imunológico na doença renal crônica. Biblioteca Médica Digital[Internet]. 2008[cited 2018 Jun 01]. p.1-3. Available from: http://www.flumignano.com/medicos/Download/VITAMINA_D_E_DOENCA_RENAL_CRONICA.pdf

7. Gal-Moscovici A, Sprague SM. Role of vitamin D deficiency in chronic kidney disease. J Bone Mineral Res[Internet]. 2007[cited 2018 Jun 10];22(5):91-4. Available from: https://www.ncbi.nlm.nih.gov/pubmed/18290730

8. Marques CDL, Dantas AT, Fragoso TS, Duarte ALBP. The importance of vitamin D levels in autoimmune diseases. Rev Bras Reumatol[Internet]. 2010[cited 2018 Jun 20];50(1):67-80. Available from: http://www.scielo.br/pdf/rbr/v50n1/en_v50n1a07.pdf

9. Nigwekar SU, Tamez H, Thadhani R. Vitamin D and chronic kidney disease-mineral bone disease (CKD-MBD). BoneKEy Rep[Internet]. 2014[cited 2018 May 20];498:1-6. Available from: https://www.ncbi.nlm.nih.gov/pmc/articles/PMC3944129/

10. Dusso AS, Brown AJ, Slatopolsky E. Vitamin D. Am J Physiol Renal Physiol[Internet]. 2005[cited 2018 Jun 25];289: F8-F28. Available from: https://www.physiology.org/doi/pdf/10.1152/ajprenal.00336.2004

11. Brasil. Agência Nacional de Vigilância Sanitária-ANVISA. Indicadores Nacionais de Infecções Relacionadas à Assistência à Saúde. Unidade de Investigação e Prevenção das Infecções e Eventos Adversos - UIPEA[Internet]. 2010[cited 2018 May 16]. Available from: http://portal.anvisa.gov.br/documents/33852/271855/Indicadores + Nacionais + de + Infec \%C3\%A7\%C3\%B5es + Relaciona das $+\%$ C3 $\% A 0+$ Assist $\% C 3 \% A A n c i a+\% C 3 \% A 0+$ Sa $\%$ C3 $\%$ BAde/daef83da-e2ac-477e-8141-a31f3146a2c6

12. Iwagami M, Caplin B, Smeeth L, Tomlinson LA, Nitsch D. Chronic kidney disease and cause-specific hospitalisation: a matched cohort study using primary and secondary care patient data. Br J Gen Pract[Internet]. 2018[cited 2018 Jul 31];68(673):e512-e523. Available from: https://bjgp.org/content/68/673/e512/tab-pdf

13. Normand I, Elftouh N, Lafrance JP. Association between active vitamin D and the risk of infection related hospitalizations in patients receiving chronic hemodialysis: a nested case control study. Pharmacoepidemiol Drug Saf[Internet]. 2013 [cited 2018 Jul 01];22(Suppl-1):183-4. Available from: https://www.ncbi.nlm.nih.gov/pubmed/24470433

14. Phyo N, Agarwal G, Gelfond J, Bansal S. Ergocalciferol supplementation does not reduce the rate of infections and all causes mortality in hemodialysis (HD) patients. Am J Kidney Dis[Internet]. 2015[cited 2018 Jul 03];65:4(A67). Available from: https:// www.ajkd.org/article/S0272-6386(15)00304-2/pdf

15. Teng M, Wolf M, Lowrie E, Ofsthun MN, Lazarus M, Thadhani R. Survival of patients undergoing hemodialysis with paricalcitol or caltiriol therapy. N Engl J Med[Internet]. 2003[cited 2018 Jun 10];349(5):446-56. Available from: https://www.nejm.org/doi/ pdf/10.1056/NEJMoa022536

16. Teng M, Wolf M, Ofsthun MN, Lazarus M, Hernán MA, Camargo CA, et al. Actived injectable vitamin D and hemodialysis survival: a historical cohort study. J Am Soc Nephrol[Internet]. 2005[cited 2018 Jun 01];16:115-125. Available from: http://jasn.asnjournals. org/content/16/4/1115.full.pdf + html

17. Brasil. Ministério da Saúde. Resolução Conselho Nacional de Saúde nº 466, de 12 de dezembro de 2012.

18. Von Elm E, Altman DG, Egger M, Pocock SJ, Gotzsche PC, Vandenbroucke JP, et al. The Strengthening the Reporting of Observational Studies in Epidemiology (STROBE) Statement: guidelines for reporting observational studies. J Clin Epidemiol[Internet]. 2008[cited 2018 May 18];61(4):344-9. Available from: http://www.equator-network.org/reporting-guidelines/strobe/

19. Draime JA. Panorama da doença renal crônica no Brasil e no mundo. Universidade Federal do Maranhão[Internet]. São Luís: UNASUS/UFMA; 2014[cited 2018 May 18]. Available from: https://ares.unasus.gov.br/acervo/handle/ARES/2028

20. Brasil. Ministério da Saúde. Secretaria de Atenção à Saúde. Departamento de Atenção Especializada e Temática. Diretrizes Clínicas para o Cuidado ao paciente com Doença Renal Crônica - DRC no Sistema Único de Saúde[Internet]. Brasília: Ministério da Saúde; 2014[cited 2018 May 25]. Available from: http://bvsms.saude.gov.br/bvs/publicacoes/diretrizes_clinicas_cuidado_paciente_renal.pdf

21. United States Renal Data System. 2015 USRDS annual data report: Epidemiology of Kidney Disease in the United States[Internet]. 
Bethesda, MD: National Institutes of Health, National Institute of Diabetes and Digestive and Kidney Diseases; 2015 [cited 2018 May 25]. Available from: https://www.usrds.org/2015/download/vol1_USRDS_CKD_15.pdf

22. Lesley A, Astor BC, Fox CH, Isakova T, Lash JP, Peralta CA, et al. KDOQI US Commentary on the 2012 KDIGO Clinical Practice Guideline for the Evaluation and Management of CKD. Am J Kidney Dis[Internet]. 2014[cited 2018 May 08];63(5):713-35. Available from: https://www.ajkd.org/article/S0272-6386(14)00491-0/pdf

23. Sesso RC, Lopes AA, Thomé FS, Lugon JR, Carmen TM. Brazilian Chronic Dialysis Survey 2016. J Bras Nefrol[Internet]. 2017[cited 2018 May 25];39(4):261-6. Available from: http://www.scielo.br/pdf/jbn/v39n3/0101-2800-jbn-39-03-0261.pdf

24. Go AS, Chertow GM, Fan D, McCullock CE, Hsu C. Chronic kidney disease and the risks of death, cardiovascular events, and hospitalization. New Eng J Med[Internet]. 2004[cited 2018 Jun 14];351:1296-305. Available from: https://www.nejm.org/doi/ pdf/10.1056/NEJMoa041031

25. Medeiros MCWC, Sá MPC. Adherence of the carriers of chronic renal disease to the conservative treatment. Rev Rene[Internet]. 2011[cited 2018 Jun 18];12(1):65-72. Available from: http://www.periodicos.ufc.br/rene/article/viewFile/4135/3217

26. Maeda SS, Borba VZ, Camargo MB, Silva DM, Borges JL, Bandeira F, et al. Recommendations of the Brazilian Society of Endocrinology and Metabology (SBEM) for the diagnosis and treatment of hypovitaminosis D. Arq Bras Endocrinol Metab[Internet]. 2014[cited 2018 Jun 14];58(5):411-33. Available from: http://www.scielo.br/pdf/abem/v58n5/en 0004-2730-abem-58-5-0411.pdf

27. Echida Y, Mochizuki T, Uchida K, Tsuchiya K, Kosaku N. Risk Factors for Vitamin D Deficiency in Patients with Chronic Kidney Disease. Intern Med[Internet]. 2012[cited 2018 Jul 22];51(8):845-50. Available from: https://www.jstage.jst.go.jp/article/ internalmedicine/51/8/51_8_845/_pdf/-char/en

28. Gonçalves JG, Bragança AC, Canale D, Shimizu MH, Sanches TR, Moysés RM, et al. Vitamin D deficiency aggravates chronic kidney disease progression after ischemic acute kidney injury. PLoS One[Internet]. 2014[cited 2018 Jul 19];9(9):e107228. Available from: http://journals.plos.org/plosone/article/file?id=10.1371/journal.pone.0107228\&type = printable

29. Galunska BT, Gerova DI, Paskalev DN, Zorcheva RY, Ikonomov VC, Vladimirov V, et al. Prevalence of vitamin D deficiency in different groups of chronic renal. J IMAB[Internet]. 2015[cited 2018 Jul 14];21(3):887-90. Available from: https://www.journalimab-bg.org/issues-2015/issue3/JofIMAB_2015-21-3p887-890.pdf

30. Bucharles S, Barberato SH, Stinghen AE, Gruber B, Meister H, Mehl A, et al. Hypovitaminosis D is associated with systemic inflammation and concentric myocardial geometric pattern in hemodialysis patients with low iPTH levels. Nephron Clin Pract[Internet]. 2011[cited 2018 May 08];118:c384-c391. Available from: https://www.karger.com/Article/Pdf/323664

31. Pilz S, lodice S, Zittermann A, Grant WB, Gandini S. Vitamin D status and mortality risk in CKD: a meta-analysis of prospective studies. Am J Kidney Dis[Internet]. 2011 [cited 2018 Jul 22];58(3):374-82. Available from: https://www.ajkd.org/article/S0272-6386(11)00739-6/pdf

32. Fram D, Okuno MF, Taminato M, Ponzio V, Manfredi SR, Grothe C, et al. Risk factors for bloodstream infection in patients at a Brazilian hemodialysis center: a case-control study. BMC Infect Dis[Internet]. 2015[cited 2018 Jun 26];15(158):1-9. Available from: https://bmcinfectdis.biomedcentral.com/track/pdf/10.1186/s12879-015-0907-y

33. Grothe C, Belasco AGS, Bittencourt ARC, Vianna LA, Sesso RCC, Barbosa DA. Incidence of bloodstream infection among patients on hemodialysis by central venous cateter. Rev Latino-Am Enfermagem[Internet]. 2010[cited 2018 Jun 25];18(1):73-80. Available from: http://www.scielo.br/pdf/rlae/v18n1/12.pdf

34. Fiedler R, Dorligjav O, Seibert E, Ulrich C, Markau S, Girndt M. Vitamin D deficiency, mortality, and hospitalization in hemodialysis patients with or without protein-energy wasting. Nephron Clin Pract[Internet]. 2011 [cited 2018 Jul 25];119(3):c220-6. Available from: https://www.karger.com/Article/Pdf/328927

35. Chonchol M, Kendrick J, Targher G. Extra-skeletal effects of vitamin D deficiency in chronic kidney disease. Ann Med[Internet]. 2011[cited 2018 Jul 29];43(4):273-82. Available from: https://www.ncbi.nlm.nih.gov/pmc/articles/PMC4030714/pdf/nihms576535.pdf

36. Bedi P, Hayde N, Kamal L, Ajaimy M, Lubetzky M, DeBoccardo G, et al. Prospective monitoring of 25-hydroxyvitamin vitamin D levels after kidney transplantation and its associations with clinical outcomes. American journal of transplantation. Conference: 17th American Transplant Congress-ATC[Internet]. 2017[cited 2018 Jul 29]; 17:798. Available from: https://atcmeetingabstracts.com/abstract/ prospective-monitoring-of-25-hydroxyvitamin-vitamin-d-levels-after-kidney-transplantation-and-its-associations-with-clinical-outcomes/

37. Tsujimoto $\mathrm{Y}$, Tahara H, Shoji T, Emoto $M$, Koyama $H$, Ishimura E, et al. Active vitamin $D$ and acute respiratory infections in dialysis patients. Clin J Am Soc Nephrol[Internet]. 2011[cited 2018 May 03];6:1361-7. Available from: http://cjasn.asnjournals. org/content/6/6/1361.full.pdf + html

38. Kerschbaum J, Vychytil A, Lhotta K, Prischl FC, Wiesholzer M, Machhold-Fabrizii V, et al. Treatment with oral active vitamin D is associated with decreased risk of peritonitis and improved survival in patients on peritoneal dialysis. PLoS One[Internet]. 2013[cited 2018 May 24];8(7):e67836. Available from: https://doi.org/10.1371/journal.pone.0067836 